Сапрыкин Владимир Александрович

кандидат социологических наук, доцент кафедры философии, социальных наук и журналистики Елецкого государственного университета имени И.А. Бунина

\section{ДЕСТРУКТИВНОЕ ПОВЕДЕНИЕ МОЛОДЕЖИ В УСЛОВИЯХ ИНФОРМАЦИОННОЙ ВОЙНЫ: КОЛУМБАЙН-ВЫЗОВЫ И МЕРЫ ПРЕОДОЛЕНИЯ}

Аннотация:

В статье проводится анализ деструктивной формы социального поведения молодежи на примере массового убийства в Керченском колледже. Рассматривается феномен крымского колумбайна с точки зрения его роли в условиях информационной войны. Демонстрируется, что проблема деструктивного поведения молодежи в условиях информационной войны имеет комплексный характер, основательно связана как с институтами социализации, так и с государственными структурами. Отмечена воспитательная роль школьной организации для учащихся мужского пола в рамках формирования у них реальных представлений о жизни на основе позитивных образцов мужественности учителеймужчин. Подчеркнута значимость формирования государственной информационной политики в СМИ, системе образования, сфере социально-культурного строительства. Приведены примеры основ новой системы управления социокультурным контентом в интересах российского государства, отечественной культуры. Представлена важность разработки отечественных компьютерных игр, формирования кинематографа, работающего в направлении воспитания патриотизма в молодежи. Предложены меры для решения проблемы деструктивного поведения современной молодежи.

\section{Ключевые слова:}

деструктивное поведение молодежи, информационная война, консциентальная война, молодежь, система образования, девиации, компьютерные игры, фильмы, средства массовой информации, информационная политика.
Saprykin Vladimir Aleksandrovich

PhD in Social Science, Associate Professor, Philosophy, Social Science and Journalism Department, Bunin Yelets State University

\section{DESTRUCTIVE BEHAVIOR OF YOUTH IN THE CONTEXT OF THE INFORMATION WAR: COLUMBINE CHALLENGES AND MEASURES TO OVERCOME THEM}

Summary:

The paper analyzes the destructive social behavior of young people by a case study of the massacre in Kerch College. The phenomenon of Crimean Columbine is considered in terms of its role in the information war The research demonstrates that destructive behavior of youth in the context of the information war is of an integrated nature. It is associated with both the institutions of socialization and government agencies. The study notes the educational role of schools in developing real ideas about life among male students based on positive examples of courage demonstrated by male teachers. In the author's opinion, it is important to establish the public information policy on media, education system, social and cultural development. The paper describes the bases of a new control system of sociocultural content for the benefit of the Russian state and culture in detail. The authors believe that Russian computer games and movies should be created in the context of patriotic education of young people. The measures to solve the problem of destructive behavior of modern youth are presented as well.

Keywords:

destructive behavior of youth, information war, consciental war, youth, education system, deviations, computer games, movies, media, information policy.

В рамках изучения деструктивного поведения молодежи в условиях информационной войны рассмотрим феномен крымского колумбайна. 17 октября 2018 г. в Крыму студент колледжа устроил массовое убийство обучающихся. Пострадало 67 человек. Произошедшее журналисты назвали крымским колумбайном.

Ведущуюся информационную войну определим как консциентальную войну - военные действия по захвату и формированию нужного социального сознания (средствами кинематографа, компьютерных игр и т. д.) [1].

Колумбайн - это пример девиантного поведения как отклонения от культурных и правовых норм, влекущего за собой соответствующее наказание. Для изучения колумбайна актуальны социальные исследования девиантного поведения. Это исследования Р.К. Мертона (причиной девиантного и деструктивного поведения считал аномию), П. Штомпки (прослеживал травматические социальные изменения в современном обществе), 3. Баумана (изучал усиление в индивидуализированном обществе роли неконтролируемых человеком сил и тенденций), Е.М. Бабосова (исследовал взаимодействие людей в экстремальных условиях кризисов), Я.И. Гилинского (изучал социологию преступности, развивал научные положения девиантологии) и др. [2]. 
Колумбайн - феномен, суть которого состоит в том, что под воздействием современной массовой культуры (фильмов ужасов, боевиков, компьютерных игр - «шутеров» и др.) и под влиянием «деструктив-групп» в социальных сетях у молодых людей формируются разрушительные поведенческие установки, они устраивают кровавые побоища в местах массового скопления людей.

В России появились молодые люди - потенциальные носители идеи и способа социального влияния под названием «колумбайн» (произошло от наименования американского населенного пункта, в одной из образовательных организаций которого в 1999 г. случилось кровавое побоище, унесшее жизни учащихся) [3]. Распространение сетевых технологий резко расширило круг общения современных молодых людей (в возрасте от 12 лет и старше), осуществлять социальный контроль над которым в должной мере не в состоянии ни родители, ни общественность. Современные компьютерные игры своей концепцией продвигают деструктивное социальное поведение. Молодые люди смотрят художественные фрильмы, эстетика которых подразумевает различные девиации: хулиганство, убийство, людоедство, бесчеловечность, изуверство и т. п. Они погружены в экранную культуру, транслирующую образы частых убийств, где педалируется ложная правильность уничтожения того, кто не нравится, кто другой. Следует подчеркнуть, что в информационной среде современных СМИ идет поэтизация греха, стирание табу человекоубийства, навязывание ложного выбора между социально одобряемым и социально неодобряемым, подсознательное впечатывание динамичных образов убийств (чаще всего символических) как способов решения всех проблем [4].

Некоторые молодые люди после компьютерных игр и просмотра фильмов держат себя в руках и не проявляют агрессии [5]. Другие становятся уязвимыми: с ними легко вступить в контакт, можно даже бессознательно «подселить» к ним кого-нибудь (как внутреннего советчика, своеобразного наставника) и удаленно ввести, к примеру через «синего кита», деструктивный набор психоустановок, таким образом формируя агрессивное поведение, что позволяет констатировать управляемость данного процесса [6].

В России наступает новый период, когда с вышеописанным феноменом придется иметь дело. Считаем, что в России сформировалась неправильная реакция на колумбайн-вызовы: родителям и представителям общественности закрыли доступ в общеобразовательные школы. При этом замалчивается и не решается реальная проблема: в школах критически мало мужчин-учителей (от общей численности кадрового состава), вынужденно транслируется «женский образец» воспитания. Учителя как агенты первичной социализации недостаточно формируют «мужской пример» для мальчиков, находящихся в границах риска и готовых выйти за пределы моральных ограничений (вплоть до убийства).

Представим понимание решения проблемы колумбайна. В основу положим результаты группового, фокусированного интервью лидеров (10 человек) общественных организаций Липецкой области на тему «Деструктивное поведение молодежи (на примере массового убийства в Керченском колледже)» (ноябрь 2018 г.). По мнению участников фокус-группы, государственные структуры должны инициировать разработку и реализацию комплекса стратегических мер, направленных на нейтрализацию угроз, создаваемых деструктивными элементами современного западного социума и продвигаемых посредством масскультуры и сетевых технологий, что позволит впредь не допустить возникновения ситуаций, аналогичных керченской трагедии.

Опираясь на результаты фокус-группового интервью, а также мнения, оценки, суждения современных исследователей, политиков, управленцев, предлагаем следующий комплекс мер, методологическое обеспечение которых включает методы аналитической интерпретации полученных данных, ранжирования, структурно-функционального анализа.

Во-первых, считаем целесообразным на основе существующих запросов населения России формировать государственную информационную политику посредством широкого общественного обсуждения, в том числе с помощью СМИ [7]. Это обсуждение обеспечит обратную связь между органами госуправления и обществом, что позволит отразить в информационной политике общественные ожидания и обеспечить ее широкую социальную поддержку.

Во-вторых, так как сложившаяся система формального образования не пользуется широкой социальной поддержкой [8], считаем, что назрела необходимость разработки комплекса стратегических мер в этой сфрере, позволяющих учесть общественные интересы. Например, предлагаем принять меры по изменению образа учителя в социальном сознании, так как сложившийся образ учителя как человека, предоставляющего услугу, не подходит для формирования сознания учащихся в связи с тем, что учитель в данном случае не выступает значимым взрослым, с мнением которого нужно считаться. Полагаем, что оправданным будет изменение системы оплаты труда учителей с возвратом к единой тарифной сетке и нормативным определением условий начисления стимулирующих надбавок, что позволит привлечь в школу более квалифицированные кадры и мобилизовать мужчин-учителей с успешным опытом жизнедеятельности, с ощущением собственного призвания учителя, социально неравнодушных, с любовью относящихся к де- 
тям. Такие мужчины будут востребованы в школах в рамках модели формирования образа-примера состоявшегося человека для подростков. Считаем оправданным создание на основе родительских комитетов посредством социальных сетей (WhatsApp, Viber, «ВКонтакте» и др.) социальных групп и коммуникационных площадок для обсуждения и профрилактики различных социальных проблем, в том числе проблемы колумбайна. Это позволит на базе школьных округов формировать социальные платформы, аккумулирующие общественное мнение, которое далее может преобразовываться в общественные поручения региональным депутатам для принятия законодательных инициатив, способствующих пресечению деструктивного поведения молодежи.

В силу того, что формальное школьное образование не является социально изолированной системой, представляется социально востребованным формирование комплекса мер по госуправлению системой образования и неформальной ее частью в СМИ, интернете, социальных сетях, в том числе на интернет-форумах. Это позволит государству контролировать современный электронный контент, в том числе индустрию компьютерных (в частности, обучающих) игр. Кроме того, считаем необходимым продолжить формировать систему управления киноконтентом посредством финансирования патриотически ориентированных кинокартин. В рамках современной государственной политики целесообразным будет возрождение госкомиссии по кинофикации и кинопрокату, что позволит оградить молодежь от негативного влияния киноконтента, содержащего кровавые сцены и демонстрирующего различные способы человекоубийства.

B-третьих, соглашаясь с военными экспертами, считаем необходимым создание аналитической спецслужбы по консциентальному противостоянию, что позволит обеспечивать государственную безопасность в сфере смыслов [9], организовывать наблюдение не только за террористическими организациями (запрещенными на территории РФ), перемещением наркотиков, оружия, но и за потоками информации в социальных сетях, в которых осуществляется вербовка жителей России террористическими организациями [10].

Полагаем, что при условии реализации вышеперечисленных мер изменится система социального контроля в сторону предотвращения девиаций. При этом стоит отметить, что в России есть политический и военный суверенитеты, на государственном уровне ведется работа по строительству государственного суверенитета в информационной, культурной, финансовой, образовательной сферах. Примером могут служить результаты деятельности российских компаний InfoWatch, «Крибрум», выполняющих господряды. Показателен опыт деятельности компании «Ашманов и партнеры» по выявлению в инфосети агентов, вовлекающих молодежь в девиации.

Таким образом, проблема деструктивного поведения молодежи в условиях информационной войны имеет комплексный характер, основательно связана как с институтами социализации, так и с государственными структурами.

\section{Ссылки:}

1. Громыко Н.В. Использование информационных технологий в качестве «консциентального оружия» [Электронный ресурс] // Восток : альманах. 2005. № 7/8 (31/32). Июль - август. URL: http://www.situation.ru/app/j_art_984.htm (дата обращения: 10.12.2018).

2. См.: Бабосов Е.М. Катастрофы: социологический анализ. Минск, 1995. 472 с. ; Бауман 3. Индивидуализированное общество. М., 2002. 390 с. ; Гилинский Я.И. Девиантология: социология преступности, наркотизма, проституции, самоубийств и других «отклонений». 3-е изд., испр. и доп. СПб., 2013. 632 с. ; Мертон Р. Социальная теория и социальная структура. М., 2006. 873 с. ; Штомпка П. Социология социальных изменений. М., 1996. 416 с. ; Его же. Социальное изменение как травма (статья первая) // Социологические исследования. 2001. № 1. С. 6-16.

3. Rice A.C. Researchers Study School Shooting [Электронный ресурс] // Magazine University of Northern Colorado. 2016. May 3. URL: https://www.unco.edu/unc-magazine/features/school-shooting.aspx (дата обращения: 10.12.2018).

4. Буркова В.Н., Бутовская М.Л. Насильственные компьютерные игры и проблемы агрессивного поведения детей и подростков // Вопросы психологии. 2012. № 1. С. 132-140.

5. Попов В.А., Валькова Л.С. Влияние компьютерных игр на уровень агрессивности подростков // Молодой ученый. 2014. № 7 (66). C. 279-281.

6. Bowers E.Sh. School Shooters - Inside Their Minds [Электронный ресурс] // Theory to Practice. 2013. No. 5. URL: https://ed.lehigh.edu/theory-to-practice/2013/school-shooters (дата обращения: 10.12.2018).

7. Российское общество после президентских выборов-2018: запрос на перемены [Электронный ресурс] : информ.аналит. докл. ФНИСЦ РАН. М., 2018. 55 c. URL: http://www.isras.ru/files/File/publ/Ros_obschestvo_posle_prezident_vyborov_2018.pdf (дата обращения: 21.01.2019).

8. См.: С̆стема образования в России: 1991-2016 [Электронный ресурс] // ВЦИОМ. 2016. № 3022. 22 янв. URL: https://wciom.ru/index.php?id=236\&uid=115556 (дата обращения: 21.01.2019) ; ЕГЭ-2018: общественная оценка [Электронный ресурс] // Там же. 2018. № 3705. 5 июля. URL: https://wciom.ru/index.php?id=236\&uid=9195 (дата обращения: 10.12.2018)

9. Макаров В.М. Консциентальная война: мифр или реальность? // Наука и военная безопасность. 2003. № 2. С. 18-22.

10. Ларина Е., Овчинский В. Кибервойны XXI в. М., 2014. 380 с.

\section{References:}

Babosov, EM 1995, Disasters: a Sociological Analysis, Minsk, 472 p., (in Russian). 
Bauman, Z 2002, Individualized Society, Moscow, 390 p., (in Russian).

Bowers, ESh 2013, 'School Shooters - Inside Their Minds', Theory to Practice, no. 5, viewed 10 December 2018, $<$ https://ed.lehigh.edu/theory-to-practice/2013/school-shooters>.

Burkova, VN \& Butovskaya, ML 2012, 'Violent Computer Games and the Problems of Aggressive Behavior of Children and Adolescents', Voprosy psikhologii, no. 1, pp. 132-140, (in Russian).

'Education System in Russia: 1991-2016' 2016, VTs/OM, no. 3022, Jan. 22, viewed 21 January 2019, <https://wciom.ru/index.php?id=236\&uid=115556>, (in Russian).

Gilinsky, Yal 2013, Deviantology: a Sociology of Crime, Drug Addiction, Prostitution, Suicide, and Other "Deviations", $3^{\text {rd }}$ ed., St. Petersburg, 632 p., (in Russian).

Gromyko, NV 2005, 'The Use of Information Technology as a "Weapon of Concern"', Vostok: al'manakh, no. 7/8 (31/32), July - August, viewed 10 December 2018, <http://www.situation.ru/app/j_art 984.htm>, (in Russian).

Larina, E \& Ovchinsky, V 2014, Cyberwars XXI, Moscow, 380 p., (in Russian).

Makarov, VM 2003, 'Consular War: Myth or Reality?', Nauka i voyennaya bezopasnost', no. 2, pp. 18-22, (in Russian).

Merton, R 2006, Social Theory and Social Structure, Moscow, 873 p., (in Russian).

Popov, VA \& Valkova, LS 2014, 'The Influence of Computer Games on the Level of Aggressiveness of Adolescents', Molodoy uchenyy, no. 7 (66), pp. 279-281, (in Russian).

Rice, AC 2016, 'Researchers Study School Shooting', Magazine University of Northern Colorado, May 3, viewed 10 December 2018, <https://www.unco.edu/unc-magazine/features/school-shooting.aspx>.

Russian Society After the Presidential Election-2018: a Request for Change 2018, Moscow, 55 p., viewed 21 January 2019, <http://www.isras.ru/files/File/publ/Ros_obschestvo_posle_prezident_vyborov_2018.pdf>, (in Russian).

Sztompka, P 1996, Sociology of Social Change, Moscow, 416 p., (in Russian).

Sztompka, P 2001, 'Social Change as an Injury (Article One)', Sotsiologicheskiye issledovaniya, no. 1, pp. 6-16, (in Russian).

'Unified State Exam-2018: Public Assessment' 2018, VTsIOM, no. 3705, July 5, viewed 10 December 2018, <https://wciom.ru/index.php?id=236\&uid=9195>, (in Russian). 